\title{
A Survey on Voluntary Disclosure on the Internet. Empirical Evidence from 300 European Union Companies ${ }^{1}$
}

Enrique Bonsón. Universidad de Huelva. Spain.

Tomás Escobar. Universidad Pablo de Olavide. Spain.

\begin{abstract}
Nowadays, the Internet is a powerful means for companies to voluntarily disclose all kind of financial information. A wide academic literature exists on the field. Findings reveal that the financial information disclosed is wider than that normally required by accounting regulations. Furthermore, the disclosure on the Internet of compulsory information can be considered as a voluntary reporting practice in itself. In this paper, the information currently provided on the Internet by leading companies in different European countries is analyzed in order to make a comparative analysis. To achieve this goal, data from the biggest (market value) 20 companies in each European Union country have been collected. Then, statistical tests have been performed to determine the relationships between what we have called companies' transparency (dependent variable) and their sector, country of origin and size (independent variables). The results suggest that there is a statistically significant relationship between these three variables and the extent of voluntary disclosure (transparency) on the Internet.
\end{abstract}

Key words: Digital reporting, voluntary disclosure, Internet.

\footnotetext{
1 This paper was made possible by financial support from the Spanish Ministry of Science and Technology. Research project BEC2001-3356. We would like to thank Pablo Becerro, çngel Labrador and Salvador Forero, undergraduate students of the University of Huelva, for their work on Internet information retrieval. We also acknowledge the insightful comments made on an earlier draft of this work by the two anonymous reviewers.
} 


\section{INTRODUCTION}

The economic system is increasingly becoming digital. Because of low relative costs and the power of information and communication technologies, companies are using them to undertake some activities that until now they have done in more rudimentary ways.

Communication networks are changing companies' internal processes, as well as the way in which companies relate to their clients and other stakeholders. On the one hand, internal information processes are faster and more automatic than they were. Intranets allow companies to process accounting information with more efficacy and efficiency. On the other hand, the Internet allows firms to extend the number of external accounting information users at a lower cost. In this new environment, companies' capacity to exploit information technology is emerging as a key determinant of success/failure.

Current competitive environment is requiring more useful accounting information and, so, invertors, social agents, clients, suppliers, etc. are demanding, more and more, relevant corporative accounting information. Furthermore, firms are also interested in the disclosure of information beyond the legal one in order to improve their image and good name.

In this context, the dissemination of accounting information on the Internet is adding a new dimension to corporate reporting. Online, real time information will soon replace the historical financial statements at present provided by companies to stakeholders. Search and presentation capabilities of the Internet allow companies to add value to their corporate information. Companies should be able to offer to principal stakeholders a wide range of additional non-financial information that can be accessed on demand, depending on the stakeholders' interests.

At early stages, companies had Web pages to improve their corporate image. Now, firms can use the Internet to obtain some competitive advantages as well. The growth in the number of users, improvements in the speed and security of communications and the low costs of technology are allowing the Internet to become an important media for monetary and information resources. The relations between firms and investors are changing to use the many opportunities that new information and communication technologies offer. Digital reporting on the Internet is a new way for external decision-makers to access relevant accounting information. Some years ago, companies started to voluntary disclose all kind of financial and non-financial information to satisfy information demands of external users. 
In recent years, attention given to the Internet in the accounting field has certainly grown. Relating to information disclosure on the Internet, some papers analyze the use of this new media by European companies. In research conducted in June 1997 by Lymer (1998), the UK 50 leading companies were studied. The results were that out of the 46 companies which had their own web pages, 30 provided some kind of financial information on the Internet, but only $16(32 \%)$ provided a full set of accounts. In July 1998, Craven and Marston (1999) analyzed a sample of 206 companies obtained from the FTSE100 index and from the companies with high stock capitalization according to the Financial Times in January 1998. Findings included that 153 companies (74\%) had web pages. 67 companies (33\%) provided their accounts in detail, whereas $42(20 \%)$ only provided a summary.

In Germany, Deller et al. (1998) analyzed a sample of 100 companies (DAX index) and the results were that $76(76 \%)$ had Web pages. Forty-five of them (45\%) provided limited annual report accounting data and the rest gave them fully. Lymer and Tallberg (1997) reviewed the situation in Finland. The 72 companies quoted on the Helsinki's Stock Exchange were studied. Sixty-five of them (90\%) had a website, $36(50 \%)$ provided only parts or summaries of their annual reports and just $8(11 \%)$ provided a detailed annual report. In Sweden, Hedlin (1999) studied a sample of 60 companies listed in the Stockholm Stock Exchange Index. It was found that $98 \%$ of the companies had Web pages and that $83 \%$ provided their financial statements on the Internet.

In Spain, Molero et al. (1999) examined in September 1998 the state of the IBEX35 companies. They found that $29(83 \%)$ of them had Web pages and 13 companies (37\%) presented their full annual accounts on them. In the same paper, Molero et al. (1999) analyzed 215 companies listed in the Madrid Stock Exchange General Index. In this case, the results revealed less use of the Web: 96 companies (45\%) had Web pages and 18 (9\%) of them presented full accounts. In 1998, Gowthorpe and Amat (1999) studied a sample of 379 companies quoted in the Madrid Stock Exchange. 19\% of them had Web pages and 5\% gave their annual accounts.

Considering Europe as a whole, Bonsón et al. (2000) analyzed in October 1999 the digital reports of companies listed in the Dow Jones Eurostoxx50 index. $100 \%$ of the companies had a website providing their full annual accounts. $90 \%$ of them provided interim non-audited reports. $62 \%$ disclosed historical information, whereas only $38 \%$ included financial ratios. Four companies, all of them German ones, were reporting under International Accounting Standards. Twenty of the fifty studied companies (40\%) included environmental reporting. 
Interesting though all these studies are, it is not possible to make any kind of comparison between different European countries from their results, because they were conducted piecemeal. Also, they are mainly descriptive and do not try to investigate the factors determining the level of disclosure on the Internet.

In this work, we examine the extent of financial information currently provided on the Internet by the leading European companies. We studied the biggest 20 companies in each European Union country. Its aim was to identify what kind of information is provided by companies in different countries in order to make a comparative analysis. Then, we try to empirically identify the factors explaining the level of information disclosing of European companies. The results show a statistically significant relationship between the considered independent variables and the extent of voluntary disclosure on the Internet.

\section{HYPOTHESES AND DISCLOSURE INDEX}

The companies' Internet usage has evolved during the last years. At the beginning, the aim of the companies was the colonization of the new media. In this early stage, the priority was to have a web presence. Then, companies began to voluntarily disclose their financial information on the Internet to facilitate its access to external users. Nowadays, voluntary disclosure of accounting information seems to be a prevalent practice in leading worldwide companies.

Traditionally, companies have used different media to disclose voluntary information. These media include the printed annual report (Lang and Lundholm, 1993) and shareholders' meetings (Frankel et al., 1999). Usually, the disclosure takes place when it is more convenient for the company (Abbody and Kasznik, 2000; Frankel et al, 1995; Kasznik, 1999), in order to improve company' results (Dye, 1990). Nowadays, the Internet constitutes a powerful means for voluntary disclosure. It allows an increase in the number of potential users.

Different theories, including agency theory, signalling theory, cost benefit analysis and Coasian theory of the firm, have been used to explain company voluntary disclosure (Debreceny et al., 1999; Marston and Shrives, 1996). These theories could be of special relevance in an Internet disclosure environment as there is no legal duty for companies to provide information through this means. Furthermore, the disclosure on the Internet of compulsory information can be considered as a voluntary disclosure practice in itself. In summary, three reasons which motivate managers to voluntarily enhance the visibility of their firm's financial profiles can be highlighted (Debreceny et al. (1999): 
1. To reduce the risk of moral hazard in order to lower the agency costs or contracting costs (Watts, 1977).

2. To signal to the market the actual quality of the firm's securities such that the value of the firm is enhanced and/or its cost of capital is reduced (Botosan, 1997; Frankel et al., 1999; Sengupta, 1998).

3. To provide additional information that is not available through mandatory reporting so that investors can reduce their cost of transacting in the firm's securities, which in turn will reduce cost of capital and enhance firm value (Yeo and Ziebart, 1995).

Some studies have suggested that companies can decrease the cost of capital by supplying more credible information to external users (Choi, 1974; Fishman and Hagerty, 1989; Healy and Palepu, 1993; Verrechia, 1983). However, these relations can not be analyzed if other factors such as the agency costs (Gurbaxani and Whang, 1991) and the cost-benefit relation of disclosed information (Kelly, 1983) are not considered.

Information and communication technologies in general, and the Internet in special, are modifying the cost-benefit relation of voluntary disclosure. The use of the Internet allows companies to increase the number of information users, as well as to offer higher quality information at a lower cost than the information supplied by using traditional media. In this sense, the possibility of disclosing voluntary information on the Internet is considered by the companies as a new source of competitive advantages. It could allow them to improve their image to investors and other stakeholders, to reduce the capital costs, and to increase the company' market value at a lower cost of elaborating and communicating the voluntary information.

However, although the costs of voluntary disclosing on the Internet are relatively low, the amount and quality of the information supplied by European companies is very different from each other. This paper aims to analyze the information currently provided on the Internet by leading European companies and to empirically ascertain the variables that could have some influence on the amount of information disclosed. To achieve this last goal, we have considered three variables that have been used in previous works as influent variables in the information disclosed by companies using traditional media: industrial sector, country/culture and size. Therefore, we have stated the following hypotheses (in a positive sense):

H1: There is a significant association between industry type and the extent of financial disclosure on the Internet 
Industry type sometimes has been used to explain the amount of financial information provided by companies (Amernic and Maiocco, 1981; Bazley et al., 1985; Wagenhofer, 1990). In this sense, Ettredge, et al. (2001: 153) revealed that this variable affects whether companies have Web pages.

It can be argued that companies belonging to the same industrial type have similar practices voluntarily disclosing information. Two factors can be identified. On the one hand, firms in certain sector need to show a good corporate image. On the other hand, each sector has particular financial characteristics, so companies can try to reduce the cost of capital by disclosing voluntary information.

H2: The country of origin of the company determines the level of information provided.

The country of origin is another variable that has been traditionally considered to explain the information provided by companies (Craven and Otsmani, 1999; Gray, 1988; Gray et al., 1995).

This study concerns European companies. Although these companies compete in a global market, these are find important cultural differences among the European countries (Hofstede, 1991, 2001). Therefore, it can be argued that the information voluntary disclosed by companies on the Internet depends on countries' culture.

H3: Larger companies provide more information

The association between company size and the extent of financial disclosure has been widely studied. Findings show that a positive association exists (Adams and Hossain, 1998; Aitken et al., 1997; Chow and Wong-Boren, 1987; Craven and Otsmani, 1999; Lang and Lundholm, 1993; McKinnon and Dalimunthe, 1993). Pirchegger et al. (1999) provides evidence about the relation between the quality of Austrian websites and companies' size. Craven and Marston (1999) found that larger companies (measured by market value) within a sample of London Stock Exchange listed companies are more likely to disclose their financial information on the Internet.

If we analyzed works reviewed in the previous section about digital reporting in Europe, it seems that the more selective the sample is, the higher level of disclosure provided. Therefore, we can argue that a relation between companies' size and the voluntary information provided may exist. On the one hand, the larger the company, the more need for external funds. Therefore, large companies may be able to access financial markets better if they disclose more voluntary information. Furthermore, the higher number of external information users may 
press the companies for voluntary information to be disclosed. Also, the bigger the company is, the lower, in relative terms, the costs of preparing and disclosing voluntary information for external users.

We have created a transparency index (TI) to evaluate the level of disclosure provided by the companies. TI definition requires two different tasks. First, we have to define what variables are going to compose the TI, that is to say, a delimitation of the information contents to be evaluated. Second, we have to define how to value each variable, as well as to decide if a weighted or unweighted index is going to be used.

Regarding the contents to be evaluated, it is clear that we cannot limit the index to financial aspect traditionally included in corporate reports, but to include other financial/non financial and quantitative/qualitative variables. Obviously, information demands are very related to the user's profile. We have used the following works to develop our TI: AICPA (1994), Debreceny, et al. (2001), and Ettredge, et al. (2001).

The FASB, based on a previous study from the AICPA (1994), has proposed a set of information contents to be supplied through corporate Web pages. Five categories are considered: financial and non-financial data, management's analysis of the financial and non-financial data, forward-looking information, information about management and shareholders, and background about the company. Nevertheless, the AICPA's study is focused only on certain types of users, specifically professional investors and creditors and their advisors, which follow fundamental approaches and which cannot compel a company to produce the information needed for analysis.

Debreceny, et al. (2001) empirically analyze what users want in terms of content, form and navigation. Relating to contents, they address disclosures from their perspectives: (1) the financial statements, (2) corporate background and news, and (3) forecasts. They found that traditional elements of the financial statements, including the core financial statements, notes, auditors' report and annual report, are the most highly ranked information attributes. In terms of the attributes related to the form of presentation, the respondents were moderately averse to the need to download files (e.g., downloading the Adobe Acrobat Reader). In addition, they gave relatively low ratings to "bells and whistles" such as email links on the Web site. In terms of navigation, the respondents liked hyperlinks and other navigation aids such tables of content over search and query functions. Lastly, Ettredge, et al. (2001) use a checklist to evaluate the information disclosed by some companies. The checklist includes both accounting- and non-accountingbased financial items. 
Using these references, a broad set of contents has been considered in this work. Variables composing the TI are listed in table 1.

Table 1

Variables composing the TI

\begin{tabular}{|c|c|}
\hline VARIABLE & DESCRIPTION \\
\hline V.1. & $\begin{array}{l}\text { Balance sheet and income statement }(\mathrm{Html} \text { or Pdf).- full } \\
\text { financial statements, not isolated figures, in Html or Pdf } \\
\text { format. }\end{array}$ \\
\hline V.2. & $\begin{array}{l}\text { Balance sheet and income statement (Excel).- full financial } \\
\text { statements, not isolated figures, in Excel format. }\end{array}$ \\
\hline V.3. & $\begin{array}{l}\text { Cash flow statement (Html or Pdf).- full cash flow statement } \\
\text { in Html or Pdf format. }\end{array}$ \\
\hline V.4. & $\begin{array}{l}\text { Cash flow statement (Excel).- full cash flow statement in Excel } \\
\text { format. }\end{array}$ \\
\hline V.5. & Audit report. \\
\hline V.6. & $\begin{array}{l}\text { Interim financial statements (Html or Pdf).- any kind of interim } \\
\text { information in Html or Pdf format. }\end{array}$ \\
\hline V.7. & $\begin{array}{l}\text { Interim financial statements (Excel).- any kind of interim } \\
\text { information in Excel format. }\end{array}$ \\
\hline V.8. & $\begin{array}{l}\text { Previous years financial statements }(\mathrm{Html} \text { or Pdf }) \text {. full } \\
\text { financial statements, not isolated figures, in } \mathrm{Html} \text { or Pdf } \\
\text { format, from at least the last three years. }\end{array}$ \\
\hline V.9. & $\begin{array}{l}\text { Previous years financial statements (Excel).- full financial } \\
\text { statements, not isolated figures, in Excel format, from at least } \\
\text { the last three years. }\end{array}$ \\
\hline V.10. & $\begin{array}{l}\text { Forward looking information.- any kind of forward looking } \\
\text { accounting information. }\end{array}$ \\
\hline V.11. & Financial ratios. \\
\hline V.12. & $\begin{array}{l}\text { Financial information according to International Accounting } \\
\text { Standards. }\end{array}$ \\
\hline V.13. & Information on corporate strategy. \\
\hline V.14. & Environmental information. \\
\hline V.15. & Shareholders' structure. \\
\hline V.16. & Shareholders' news. \\
\hline V.17. & Shareholders' meetings information. \\
\hline
\end{tabular}




\begin{tabular}{|c|l|}
\hline V.18. & Information on intellectual capital. \\
\hline V.19. & $\begin{array}{l}\text { Information about managers.- at least, identity and curriculum } \\
\text { vitae of executives. }\end{array}$ \\
\hline V.20. & $\begin{array}{l}\text { Information about employees.- at least, number of employees } \\
\text { and geographical distribution. }\end{array}$ \\
\hline V.21. & $\begin{array}{l}\text { Information on operations abroad.- at least, inversions and } \\
\text { sales in each country. }\end{array}$ \\
\hline V.22. & $\begin{array}{l}\text { Press releases.- updated information about the presence of } \\
\text { the company in informative media. }\end{array}$ \\
\hline V.23. & Mailing lists. \\
\hline
\end{tabular}

In contrast to other works that include some variables to evaluate the navigability and design of Web pages (Ettredge, et al., 2001; Pirchegger et al., 1999), and given that our objective is to measure voluntary information disclosed by companies, we have only considered variables referring to contents. We have also included in the TI four variables to value companies supplying financial information in Excel format in order to facilitate its analysis by decision-makers ${ }^{2}$.

The next question is to decide whether we are going to use a weighted or an unweighted index, as well as the value of the different variables. The use of a weighted index demands the determination of the relative importance of items to different users. So, to avoid the arbitrariness inherent to this process, and following to Giner (1997), in this paper we have used an unweighted index. In relation to the values of each variable, they are pointed using 1 or 0 depending on its disclosure on the Internet (Pirchegger et al., 1999). This kind of unweighted indexes has been employed in previous works to evaluate the information disclosed by companies on the Internet (Ettredge, et al., 2001). Furthermore, the TI is calculated as follows. Its maximum value is 23 and its minimum one is 0 .

$\mathrm{TI}=\mathrm{V} .1+\mathrm{V} .2+\mathrm{V} .3+\mathrm{V} .4+\mathrm{V} .5+\mathrm{V} .6+\mathrm{V} .7+\mathrm{V} .8+\mathrm{V} .9+\mathrm{V} .10+\mathrm{V} .11+\mathrm{V} .12+$ $\mathrm{V} .13+\mathrm{V} .14+\mathrm{V} .15+\mathrm{V} .16+\mathrm{V} .17+\mathrm{V} .18+\mathrm{V} .19+\mathrm{V} .20+\mathrm{V} .21+\mathrm{V} .22+\mathrm{V} .23$

\section{THE SURVEY AND RESULTS}

The aim of this work is to analyse the information currently provided on the Internet by leading European companies and to empirically find out the factors

\footnotetext{
${ }^{2}$ In this study, all companies providing financial information in Excel format are also offering it in Html or Pdf format. Furthermore, the TI allows to assign two points to those companies using Excel format and one point when companies use only $\mathrm{Html}$ or Pdf format.
} 
that could have some influence on the amount of information disclosed. To achieve this goal, data from the biggest 20 companies of each European Union country were collected in July and August 2001. The variables used to identify the companies were: name of the company; country of origin; industry sector (using the FTSE Global Classification System); and size (market value of the company in millions of Euros). To find the Websites for the companies we tried the URL's company.com or company.country. Only a few companies were not found by using this method and it was necessary to use different search tools to locate them.

Table 2 summarizes the frequency of each variable in the index. The column "Variable" shows the analyzed variable. The column "\% Companies" contains the percentage of companies that supply each item. Lastly, in the column "Order" we have ordered the variables depending on the frequency. For example, $73 \%$ of the companies in the sample provided the cash flow statement either in Html or Pdf (V.3), which is the fourth most disclosed item.

Table 2

Items disclosed by companies

\begin{tabular}{|c|c|c|}
\hline Variable & \% Companies & Order \\
\hline V.1. & 86.3 & 1 \\
\hline V.2. & 9.7 & 18 \\
\hline V.3. & 73.0 & 4 \\
\hline V.4. & 6.0 & 20 \\
\hline V.5. & 77.0 & 3 \\
\hline V.6. & 71.0 & 6 \\
\hline V.7. & 5.7 & 22 \\
\hline V.8. & 69.0 & 7 \\
\hline V.9. & 4.7 & 23 \\
\hline V.10. & 18.7 & 16 \\
\hline V.11. & 60.0 & 9 \\
\hline V.12. & 14.7 & 17 \\
\hline
\end{tabular}

\begin{tabular}{|c|c|c|}
\hline Variable & \% Companies & Order \\
\hline V.13. & 72.7 & 5 \\
\hline V.14. & 46.0 & 14 \\
\hline V.15. & 59.3 & 10 \\
\hline V.16. & 58.7 & 11 \\
\hline V.17. & 43.3 & 15 \\
\hline V.18. & 6.0 & 21 \\
\hline V.19. & 52.0 & 13 \\
\hline V.20. & 66.7 & 8 \\
\hline V.21. & 6.5 & 19 \\
\hline V.22. & 82.3 & 2 \\
\hline V.23. & 58.0 & 12 \\
\hline & & \\
\hline
\end{tabular}

Results show that balance sheet and income statement constitute the basis of digital reporting (86.3\%). Audit report (77.0\%), interim financial statements (71.0\%), and historical information (69.0\%) are also widely provided. The use of 
the Internet allows companies to include specific information services such as: press releases $(82.3 \%)$, mailing lists $(58.0 \%)$ or shareholders meetings $(43.3 \%)$. It is worth noting that the number of companies providing certain information, such as forward looking (18.7\%) or intellectual capital (6\%), is still low.

Once we identified the most frequent items, the companies in the sample were scored according to the TI proposed above. Results are summarized in table 3. The column "Frequency" shows the number of companies for each score. Columns "Percent" and "Cumulative percent" offer the results in relation to the whole sample. The TI statistics are shown in table 4.

Table 3

TI score for companies analyzed

\begin{tabular}{|c|c|c|c|}
\hline Score & Frequency & Percent & Cumulative percent \\
\hline 0 & 24 & 8.00 & 8.00 \\
\hline 1 & 6 & 2.00 & 10.00 \\
\hline 2 & 2 & 0.67 & 10.67 \\
\hline 3 & 4 & 1.33 & 12.00 \\
\hline 4 & 4 & 1.33 & 13.33 \\
\hline 5 & 4 & 1.33 & 14.67 \\
\hline 6 & 8 & 2.67 & 17.33 \\
\hline 7 & 6 & 2.00 & 19.33 \\
\hline 8 & 7 & 2.33 & 21.67 \\
\hline 9 & 13 & 4.33 & 26.00 \\
\hline 10 & 24 & 8.00 & 34.00 \\
\hline 11 & 23 & 7.67 & 41.67 \\
\hline 12 & 32 & 10.67 & 52.33 \\
\hline 13 & 36 & 12.00 & 64.33 \\
\hline 14 & 38 & 12.67 & 77.00 \\
\hline 15 & 24 & 8.00 & 85.00 \\
\hline 16 & 26 & 8.67 & 93.67 \\
\hline 17 & 10 & 3.33 & 97.00 \\
\hline 18 & 3 & 1.00 & 98.00 \\
\hline 19 & 3 & 1.00 & 99.00 \\
\hline 20 & 1 & 0.33 & 99.33 \\
\hline 21 & 2 & 0.67 & 100.00 \\
\hline Total & 300 & 100.00 & \\
\hline
\end{tabular}


Table 4

TI statistics

\begin{tabular}{|l|c|}
\hline Companies & 300 \\
\hline Mean & 11.06 \\
\hline Std. Dev. & 4.92 \\
\hline Minimun & 0 \\
\hline Maximun & 21 \\
\hline
\end{tabular}

Scores from the majority of companies are located in an intermediate position. Twenty-four companies obtained a score of 0 (because they did not have web pages, they did not disclose any kind of information or they did not report in English). No companies reached the maximum score of 23, just two of them obtained 21. The arithmetic mean of TI in the sample is 11.06.

H1: There is a significant association between industry type and the extent of financial disclosure on the Internet

Our aim is to verify if the information disclosed depends on the industry type. Table 5 collects the sample distribution by sectors, providing some TI statistical data.

Table 5

TI by sector

\begin{tabular}{|l|c|c|c|c|c|c|}
\hline Sectors & Companies & Percent & Mean & Std. Dev. & Min. & Max. \\
\hline 04 Mining & 2 & 0.67 & 14.50 & 0.71 & 14 & 15 \\
\hline 07 Oil \& Gas & 11 & 3.67 & 15.09 & 2.47 & 12 & 20 \\
\hline 11 Chemicals & 9 & 3.00 & 14.67 & 1.87 & 11 & 16 \\
\hline $\begin{array}{l}\text { 13 Construction \& } \\
\text { Building Materials }\end{array}$ & 14 & 4.67 & 8.00 & 6.49 & 0 & 16 \\
\hline 15 Forestry \& Paper & 6 & 2.00 & 11.83 & 5.60 & 1 & 16 \\
\hline 18 Steel \& Other Metals & 6 & 2.00 & 11.33 & 5.65 & 0 & 15 \\
\hline 21 Aerospace \& Defense & 2 & 0.67 & 12.00 & 0.00 & 12 & 12 \\
\hline 24 Diversified Industrials & 2 & 0.67 & 13.50 & 0.71 & 13 & 14 \\
\hline $\begin{array}{l}\text { 25 Electronic \& Electrical } \\
\text { Equipment }\end{array}$ & 11 & 3.67 & 12.55 & 4.63 & 4 & 19 \\
\hline $\begin{array}{l}\text { 26 Engineering \& } \\
\text { Machinery }\end{array}$ & 6 & 2.00 & 13.50 & 2.07 & 11 & 16 \\
\hline 31 Automobiles \& Parts & 6 & 2.00 & 13.17 & 5.38 & 6 & 21 \\
\hline
\end{tabular}




\begin{tabular}{|c|c|c|c|c|c|c|}
\hline $\begin{array}{l}34 \text { Household Goods \& } \\
\text { Textiles }\end{array}$ & 6 & 2.00 & 12.33 & 1.97 & 10 & 15 \\
\hline 41 Beverages & 7 & 2.33 & 12.86 & 3.18 & 8 & 16 \\
\hline $\begin{array}{l}43 \text { Food Producers \& } \\
\text { Processors }\end{array}$ & 6 & 2.00 & 9.17 & 5.71 & 0 & 15 \\
\hline 44 Health & 3 & 1.00 & 13.33 & 1.53 & 12 & 15 \\
\hline 46 Packaging & 2 & 0.67 & 14.00 & 1.41 & 13 & 15 \\
\hline $\begin{array}{l}47 \text { Personal Care \& } \\
\text { House Hold Products }\end{array}$ & 1 & 0.33 & 16.00 & 0.00 & 16 & 16 \\
\hline 48 Pharmaceuticals & 9 & 3.00 & 12.89 & 2.62 & 9 & 16 \\
\hline 49 Tobacco & 2 & 0.67 & 14.50 & 0.71 & 14 & 15 \\
\hline 51 Distributors & 5 & 1.67 & 13.40 & 2.51 & 10 & 17 \\
\hline 52 General Retailers & 8 & 2.67 & 8.25 & 5.39 & 0 & 14 \\
\hline $\begin{array}{l}53 \text { Leisure, Entertainment } \\
\& \text { Hotels }\end{array}$ & 1 & 0.33 & 15.00 & 0.00 & 15 & 15 \\
\hline 54 Media \& Photography & 14 & 4.67 & 9.36 & 5.50 & 0 & 16 \\
\hline 58 Support Services & 4 & 1.33 & 13.00 & 4.08 & 8 & 18 \\
\hline 59 Transport & 8 & 2.67 & 10.75 & 4.40 & 6 & 18 \\
\hline 63 Food \& Drug Retailers & 5 & 1.67 & 10.00 & 6.20 & 1 & 15 \\
\hline \multicolumn{7}{|l|}{67 Telecommunication } \\
\hline Services & 33 & 11.00 & 11.06 & 4.57 & 0 & 21 \\
\hline 72 Electricity & 12 & 4.00 & 11.17 & 4.65 & 1 & 17 \\
\hline 78 Water & 2 & 0.67 & 7.50 & 10.61 & 0 & 15 \\
\hline 81 Banks & 60 & 20.00 & 11.00 & 4.63 & 0 & 17 \\
\hline 83 Insurance & 12 & 4.00 & 8.00 & 6.42 & 0 & 19 \\
\hline 84 Life Assurance & 4 & 1.33 & 13.75 & 0.50 & 13 & 14 \\
\hline 85 Investment Companies & 4 & 1.33 & 3.00 & 6.00 & 0 & 12 \\
\hline 87 Speciality \& Other Finance & 2 & 0.67 & 4.50 & 6.36 & 0 & 9 \\
\hline $\begin{array}{l}89 \text { Investment Companies } \\
\text { (ineligible for indices inclusion) }\end{array}$ & 3 & 1.00 & 6.67 & 4.04 & 3 & 11 \\
\hline $\begin{array}{l}93 \text { Information } \\
\text { Technology Hardware }\end{array}$ & 3 & 1.00 & 10.00 & 6.24 & 3 & 15 \\
\hline $\begin{array}{l}97 \text { Software \& Computer } \\
\text { Services }\end{array}$ & 9 & 3.00 & 8.78 & 3.87 & 0 & 12 \\
\hline Total & 300 & 100.00 & 11.06 & 4.92 & $\mathbf{0}$ & 21 \\
\hline
\end{tabular}

In order to overcome the fact that some sectors have small number of companies, ten economic groups, according to the FTSE Global Classification System, were considered: 
EG0.- Resources: Mining and Oil \& Gas. 13 companies

EG1.- Basic Industries: Chemicals, Construction \& Building Materials, Forestry \& Paper, and Steel \& Other Metals. 35 companies

EG2.- General industrials: Aerospace \& Defence, Diversified Industrials, Electronic \& Electrical Equipment, and Engineering \& Machinery. 21 companies

EG3.- Cyclical consumer goods: Automobiles \& Parts, and Household Goods \& Textiles. 12 companies

EG4.- Non-cyclical consumer goods: Beverages, Food Producers \& Processors, Health, Packaging, Personal Care \& Household Products, Pharmaceuticals, and Tobacco. 30 companies

EG5.- Cyclical services: Distributors; General Retailers, Leisure, Entertainment \& Hotels, Media \& Photography, Support Services, and Transport. 40 companies

EG6 Non-cyclical services: Food \& Drug Retailers and Telecommunication Services. 38 companies

EG7.- Utilities: Electricity and Water. 14 companies

EG8.- Financials: Banks, Insurance, Life Assurance, Investment Companies, Speciality \& Other Finance, and Investment Companies. 85 companies

EG9.- Information technology: Hardware, and Software \& Computer Services. 12 companies

The TI statistics by economic group are shown in table 6 . 
Table 6

TI by economic group

\begin{tabular}{|c|c|c|c|c|c|}
\hline $\begin{array}{c}\text { Economic } \\
\text { group }\end{array}$ & Companies & Mean & Std. Dev. & Min. & Max. \\
\hline EG0 & 13 & 15.00 & 2.27 & 12 & 20 \\
\hline EG1 & 35 & 10.94 & 5.80 & 0 & 16 \\
\hline EG2 & 21 & 12.86 & 3.48 & 4 & 19 \\
\hline EG3 & 12 & 12.75 & 3.89 & 6 & 21 \\
\hline EG4 & 30 & 12.47 & 3.63 & 0 & 16 \\
\hline EG5 & 40 & 10.43 & 4.95 & 0 & 18 \\
\hline EG6 & 38 & 10.92 & 4.73 & 0 & 21 \\
\hline EG7 & 14 & 10.64 & 5.36 & 0 & 17 \\
\hline EG8 & 85 & 10.02 & 5.30 & 0 & 19 \\
\hline EG9 & 12 & 9.08 & 4.27 & 0 & 15 \\
\hline Total & $\mathbf{3 0 0}$ & $\mathbf{1 1 . 0 6}$ & $\mathbf{4 . 9 2}$ & $\mathbf{0}$ & $\mathbf{2 1}$ \\
\hline
\end{tabular}

The economic group with higher TI mean value is EG0 and the economic group with lower TI mean value is EG9. The results of the different variables by economic groups are shown in the Appendix 1. We can observe that companies belonging to EG9 tend to disclose their financial statement in Html or Pdf format, but they do not in Excel format. Also, it seems odd that these kind of companies do not supply any information about intellectual capital when one supposes that this is one of their most valuable assets. Regarding environmental information, as might be expected, companies in EG0, EG1, EG7 and EG3 have the best results whereas companies in EG9 and EG8 get the worse ones. The EG7 has the lower values in financial statements (V.1 and V.3), but it has the higher value in shareholders' structure information. Regarding information about employees, all firms in EG0 disclose this item, but only the $41,67 \%$ in EG9 do.

The existing relation between the economic groups and the information provided by companies is shown in tables 7 and 8 .

Table 7

ANOVA (economic group). Dependent variable: TI

\begin{tabular}{|l|c|c|c|c|c|}
\cline { 2 - 6 } \multicolumn{1}{c|}{} & Sum of squares & Df & Mean Square & F & Sig. \\
\hline Between groups & 521.2408 & 9 & 57.9156 & 2.5043 & $\mathbf{0 . 0 0 9 0}$ \\
\hline Within groups & 6706.7959 & 290 & 23.1269 & \multicolumn{2}{|c}{} \\
\cline { 1 - 5 } Total & 7228.0367 & 299 & \multicolumn{2}{c}{} \\
\cline { 1 - 5 } & &
\end{tabular}


Table 8

Kruskal-Wallis test (grouping variable: economic group)

\begin{tabular}{|l|c|}
\hline Test statistics & TI \\
\hline Chi-square & 25.2743 \\
\hline Df & 9 \\
\hline Asymp. Sig. & $\mathbf{0 . 0 0 2 7}$ \\
\hline
\end{tabular}

The p-values in the ANOVA (0.0090) and in the Kruskal-Wallis (0.0027) tests show that the hypothesis can be accepted. Therefore, results suggest that the information provided on the Internet varies by industry.

$\mathrm{H} 2$ : The country of origin of the company determines the level of information provided.

Our objective is to check whether or not the quantity of information provided depends on the companies' country of origin. Table 9 sums up the TI values of the companies by country.

Table 9

TI by country

\begin{tabular}{|l|c|c|c|c|c|}
\hline COUNTRY & Companies & Mean & Std. Dev. & Min. & Max. \\
\hline Austria & 20 & 12.00 & 4.57 & 0 & 17 \\
\hline Belgium & 20 & 13.15 & 2.37 & 6 & 16 \\
\hline Denmark & 20 & 11.75 & 2.84 & 7 & 17 \\
\hline Finland & 20 & 13.15 & 2.74 & 8 & 19 \\
\hline France & 20 & 11.10 & 2.34 & 6 & 16 \\
\hline Germany & 20 & 12.85 & 3.20 & 6 & 21 \\
\hline Greece & 20 & 5.35 & 3.96 & 0 & 12 \\
\hline Ireland & 20 & 10.55 & 4.65 & 1 & 17 \\
\hline Italy & 20 & 9.80 & 4.93 & 0 & 15 \\
\hline Luxemburg & 20 & 4.35 & 5.21 & 0 & 13 \\
\hline Netherlands & 20 & 15.35 & 2.13 & 12 & 20 \\
\hline Portugal & 20 & 6.25 & 5.81 & 0 & 14 \\
\hline Spain & 20 & 11.40 & 3.73 & 0 & 17 \\
\hline Sweden & 20 & 14.85 & 3.05 & 7 & 21 \\
\hline United Kingdom & 20 & 13.95 & 2.63 & 6 & 18 \\
\hline Total & $\mathbf{3 0 0}$ & $\mathbf{1 1 . 0 6}$ & $\mathbf{4 . 9 2}$ & $\mathbf{0}$ & $\mathbf{2 1}$ \\
\hline
\end{tabular}


It can be seen that there are wide differences among different European countries. If we use the TI values, four groups could be identified:

Group 1: $\quad$ Minimum value of TI $\leq$ country's TI average value $\leq$ Mean (11.06) Std.Dev./2 (4.92/2)

Luxembourg (4.35), Greece (5.35) and Portugal (6.25)

Group 2: $\quad$ Mean - Std.Dev. $/ 2<$ country's TI average value $\leq$ Mean Italy (9.80) and Ireland (10.55)

Group 3: $\quad$ Mean < country's TI average value $\leq$ Mean + Std.Dev./2 France (11.10), Spain (11.40), Denmark (11.75), Austria (12.00), Germany (12.85), Belgium (13.15) and Finland (13.15)

Group 4: $\quad$ Mean + Std.Dev. $/ 2$ < country's TI average value $\leq$ Max. value of TI The United Kingdom (13.95), Sweden (14.85) and The Netherlands (15.35)

The country with highest TI mean value is The Netherlands and the country with lowest TI mean value is Luxembourg. The results of the different variables by countries are summarised in the Appendix 2. All Dutch companies composing the sample disclose full financial statements (balanced sheet, income statement and cash flow statement). All of them also offer press releases and mailing list services. Although all Belgian and German firms supply full financial statements, only $75 \%$ of them include the audit report. We can observe that only $35 \%$ of companies in Luxembourg provide the full balanced sheet and income statement. It is a very poor rate if it is compared with other European countries. In this way, no more than $60 \%$ of analysed Portuguese companies include balance sheet and income statement in their Web pages.

The results of the ANOVA and Kruskal-Wallis tests are shown in tables 10 and 11 .

Table 10

ANOVA (country). Dependent variable: TI

\begin{tabular}{|l|c|c|c|c|c|}
\cline { 2 - 6 } \multicolumn{1}{c|}{} & Sum of squares & Df & Mean Square & F & Sig. \\
\hline Between groups & 3142.9867 & 14 & 224.4990 & 15.6625 & $\mathbf{0 . 0 0 0 0}$ \\
\hline Within groups & 4085.0500 & 285 & 14.3335 & \multicolumn{2}{|c|}{} \\
\cline { 1 - 5 } Total & 7228.0367 & 299 & \multicolumn{2}{c}{} \\
\cline { 1 - 5 } & &
\end{tabular}


Table 11

Kruskal-Wallis test (grouping variable: country)

\begin{tabular}{|l|c|}
\hline Test statistics & TI \\
\hline Chi-square & 119.4882 \\
\hline Df & 14 \\
\hline Asymp. Sig. & $\mathbf{0 . 0 0 0 0}$ \\
\hline
\end{tabular}

The p-values in the ANOVA (0.0000) and in the Kruskal-Wallis (0.0000) tests show that the hypothesis can be accepted. That is to say that the company's country of origin influences the level of information provided.

H3: Larger companies provide more information

The differences between European countries' accounting regulations create a lack of homogeneity in accounting measurements of companies' size. The different features of sectors also contribute to it. That's why the market values have been used. Four groups (Q1-4) have been created using quartiles to study the relationships between TI and market value (table 12).

Table 12

TI by size

\begin{tabular}{|l|c|c|c|c|c|}
\cline { 2 - 6 } \multicolumn{1}{c|}{} & Companies & Mean & Std. Dev. & Minimum & Maximum \\
\hline Q1 & 75 & 7,89 & 5,47 & 0 & 16 \\
\hline Q2 & 75 & 11,20 & 4,80 & 0 & 19 \\
\hline Q3 & 75 & 12,17 & 3,89 & 0 & 18 \\
\hline Q4 & 75 & 12,96 & 3,80 & 0 & 21 \\
\hline Total & $\mathbf{3 0 0}$ & $\mathbf{1 1 , 0 6}$ & $\mathbf{4 , 9 2}$ & $\mathbf{0}$ & $\mathbf{2 1}$ \\
\hline
\end{tabular}

Tables 13 and 14 show the results of ANOVA and Kruskal-Wallis tests.

Table 13

ANOVA (size). Dependent variable: TI

\begin{tabular}{|l|c|c|c|c|c|}
\cline { 2 - 6 } \multicolumn{1}{c|}{} & Sum of squares & Df & Mean Square & F & Sig. \\
\hline Between groups & 1117.2633 & 3 & 372.4211 & 18.0397 & $\mathbf{0 . 0 0 0 0}$ \\
\hline Within groups & 6110.7733 & 296 & 20.6445 & \multicolumn{2}{|c}{} \\
\cline { 1 - 5 } Total & 7228.0367 & 299 & \multicolumn{2}{|c}{} \\
\cline { 1 - 6 } & &
\end{tabular}


Table 14

Kruskal-Wallis test (grouping variable: size)

\begin{tabular}{|l|c|}
\hline Test statistics & TI \\
\hline Chi-square & 38.1254 \\
\hline Df & 3 \\
\hline Asymp. Sig. & $\mathbf{0 . 0 0 0 0}$ \\
\hline
\end{tabular}

The p-values in the ANOVA (0.0000) and in the Kruskal-Wallis (0.0000) tests show that the hypothesis can be accepted. That is to say that the company's size influences the level of information provided.

\section{CONCLUSIONS}

The Internet has proved its potential for voluntary disclosure. Companies are providing on their web sites a wide range of information, both financial and nonfinancial. Leading European companies are not an exception. In this paper, we have analyzed the information that they are currently providing on the Internet. We also have tried to empirically identify the variables that could have some influence on the amount of information disclosed.

According to the first hypothesis, the sector has been the variable used to explain the quantity of the information provided by companies. Our aim was to show if there was a significant influence of the industry type upon the quantity of information provided on the Internet. The results we have obtained lead us to the conclusion that this hypothesis can be accepted. As shown in the Appendix 1, some sectors need to voluntary disclose some kind of information (such as environmental information in industrial and utilities sectors) in order to improve their corporate image. Furthermore, firms from a particular sector seem to adopt similar disclosure practices and, if a firm does not follow these practices, it could be interpreted by market as a signal of "bad news" (Giner, 1997: 56). In this way, companies of resources and industrial sectors seem to disclose more information that companies in financial and technological sectors.

The second hypothesis established that the country of origin determines the level of information provided. According to the results, this hypothesis can also be accepted. Four groups of countries have been identified depending on the TI value. Companies from North and Central of Europe seem to have higher scores than companies from the South of Europe. For example, Dutch, Swedish, British and Finnish firms offer very good results, whereas companies from Greece, Portugal and Italy have a low score. Luxembourg is the exception to this rule 
because is the country with the lowest score. It could be explained if we consider that companies in this country are relatively small (market value) compared to other countries' ones.

Regarding to the third hypothesis, the existing relationship between the size of the company and the information provided has been previously studied. Results showed a significant relation between them. This work has led us to the same conclusion when the information is disclosed on the Internet. Large companies seem to use the Internet to reduce the information asymmetry between the firm and the investors. Large companies can supply information to a wider number of users with a relatively low cost. Furthermore, just like the sector effect, when a big company is not disclosing enough information, investors could think that the firm has poor results.

The study shows that the main European companies voluntary disclose information on the Internet. Therefore, we can say that European companies have accepted the importance of the Internet as a corporate reporting media. It has been proved that the information provided on the Internet by leading European firms depends on the sector, size and country of origin of the company.

Taken as a whole, our results suggest that European companies are very interested in digital reporting, both financial and non-financial. The use of digital reporting allows companies to attract investors world-wide and to improve relations with stakeholders. A better understanding of these practices is an important issue for future research.

\section{REFERENCES}

Abbody, D., and Kasznik, R. (2000): "CEO stock option awards and the timing of corporate voluntary disclosures", Journal of Accounting and Economics, February: 73-100.

Adams, M., and Hossain, M. (1998): "Managerial discretion and voluntary disclosure: empirical evidence from the New Zealand life insurance industry", Journal of Accounting and Public Policy, fall, vol.17, n.3:245-281.

AICPA (1994): Improving Business Reporting - A Customer Focus: Meeting the Information Needs of Investors and Creditors, Special Committee on Financial Reporting, American Institute of Certified Public Accountants, New York. 
Aitken, M., Hooper, C., and Pickering, J. (1997): "Determinants of voluntary disclosure of segment information: A re-examination of the role of diversification strategy", Accounting and Finance, may, vol.37, n.1:89-109.

Amernic, J., and Maiocco, M. (1981): "Improvements in disclosure by Canadian public companies", Cost and Management, November-December:16-20.

Bazley, M., Brown, P., and Izan, H. Y. (1985): “An analysis of lease disclosures by Australian companies", Abacus, march, vol.21, num.1:44-63.

Bonson, E., Escobar, T., and Sanchez, M. (2000): "Corporate digital reporting in Europe. A survey on Eurostoxx50 companies", Paper presented at the 3rd European Conference in Accounting Information Systems, Munich, Germany.

Botosan, C.A. (1997): "Disclosure level and the cost of equity capital", The Accounting Review, 72 (3):323-349.

Choi, F.D. (1974): "Financial disclosure in relation to a firm's capital costs", Accounting and Business Research, Autumn: 282-292.

Chow, C.W., and Wong-Boren, A. (1987): "Voluntary financial disclosure by Mexican corporations", The Accounting Review, July: 533-542.

Coase, R. (1937): “The nature of the firm”, Economica, September:386-405

Craven, B.M., and Marston, C.L. (1999): "Financial reporting on the Internet by leading UK companies", European Accounting Review, vol.8, n.2: 321-333.

Craven, B. M., and Otsmani, B. (1999): "Social and environmental reporting on the Internet by leading UK companies", Paper presented at the 22nd Annual Congress of the European Accounting Association, France.

Debreceny, R., Gray, G.L., and Mock, T.J. (2001): "Financial reporting Web sites: what users want in terms of form and content", The International Journal of Digital Accounting Research, vol.1, num.1: 1-23.

Debreceny, R., Gray, G.L., and Rahman, A. (1999): "The determinants of the Internet as a voluntary disclosure medium", Paper presented at the American Accounting Association Annual Meeting.

Deller, D., Stubenrath, M., and Weber, C. (1998): "Investor relations and the Internet. Background, potential application and evidence from the USA, UK and Germany", Paper presented at the 21st Annual Congress of the European Accounting Association, Belgium. 
Dye, R.A. (1990): "Mandatory versus voluntary disclosures", The Accounting Review, January:1-24.

Ettredge, M., Richardson, V.J., and Scholz, S. (2001): "The presentation of financial information at corporate Web sites", International Journal of Accounting Information Systems, 2: 149-168.

Fishman, M.J., and Hagerty, K.M. (1989): "Disclosure decisions by firms and the completion for price efficiency", The Journal of Finance, vol.44, num. 3:633646.

Frankel, R., Johnson, M., and Skinner, D.J. (1999): "An empirical examination of conference calls as a voluntary disclosure medium", Journal of Accounting Research, Spring:133-150.

Frankel, R. Mcnichols, M., and Wilson, G.P. (1995): "Discretionary disclosure and external financing", The Accounting Review, January:135-151.

Giner Inchausti, B. (1997): "The influence of company characteristics and accounting regulation on information disclosed by Spanish firms", European Accounting Review, vol.6, num.1: 45-68.

Gowthorpe, C., and Amat, O. (1999): "External reporting of accounting and financial information via the Internet in Spain", European Accounting Review, vol.8, n.2:365-371.

Gray, S.J. (1988): "Towards a theory of cultural influence on the development of accounting systems internationally", Abacus, 24 (1):1-15.

Gray, S.J., Meek, G.K., and Roberts, C..B. (1995): "International capital market pressures and voluntary annual report disclosures by U.S. and U.K. multinationals", Journal of International Financial Management \& Accounting, Spring: 43-69.

Gurbaxani, V., and Whang, S. (1991): "The impact of information systems on organizations and markets", Communications of the ACM.

Healy, P.M., and Palepu, K.G. (1993): "The effect of firm' financial disclosure strategies on stock prices", Accounting Horizons, vol.7, num.2:1-11.

Hedlin, P. (1999): "The Internet as a vehicle for investor information, the Swedish case", European Accounting Review, vol.8, n.2:373-381.

Hofstede, G. (1991): Cultures and Organizations, McGraw-Hill. 
Hofstede, G. (2001): Culture's Consequences, second edition, Sage Publications.

Kasznik, R. (1999): "On the association between voluntary disclosure and earnings management", Journal of Accounting Research, Spring: 57-81.

Kelly, L. (1983): "The development of a positive theory of corporate management's role in external financial reporting", Journal of Accounting Literature: 111-150.

Lang, M., and Lundholm, R. (1993): "Cross-sectional determinants of analyst ratings of corporate disclosures", Journal of Accounting Research, vol.31, n.2: 246-272.

Lymer, A. (1998): "The use of the Internet for corporate reporting. A discussion of the issues and survey of current usage in the UK", Paper presented at the 21 st Annual Congress of the European Accounting Association, Belgium.

Lymer, A., and Tallberg, A. (1997): "Corporate reporting and the Internet - a survey and commentary on the use of the WWW in corporate reporting in the UK and Finland", Paper presented at the 20th Annual Congress of the European Accounting Association, Austria.

Marston, C.L., and Shrives, P.J. (1996): "A review of the development and use of explanatory models in financial disclosure studies", Paper presented at the 19th Annual Congress of the European Accounting Association, Norway.

Mckinnon, J.L., and Dalimunthe, L.: (1993): "Voluntary disclosure of segment information by Australian diversified companies", Accounting and Finance, may, vol.33, n.1: 33-51.

Molero, J. J., Prado, A., and Sevillano, F. J. (1999): "The presentation of financial statements through the Internet: Analysis of the most significant companies in Spain", Paper presented at the 22ndAnnual Congress of the European Accounting Association, France.

Pirchegger, B., Schader, H., and Wagenhofer, A. (1999): "Financial information on the Internet. A survey of the homepages of Austrian companies", European Accounting Review, vol.8, n.2: 383-395.

Sengupta, P. (1998): "Corporate disclosure quality and the cost of debt", The Accounting Review, 73 (4): 459-474.

Verrecchia, R.E. (1983): "Discretionally disclosure", Journal of Accounting and Economics, vol.5, num.3: 179-194. 
Wagenhofer, A. (1990): "The demand for disclosure and actual disclosure by firms", Paper presented at the 13th Annual Congress of the European Accounting Association, Budapest.

Watts, R.L. (1977): "Corporate financial statements. A product of market and political process", Australian Journal of Management: 53-75.

Yeo, G.H., and Ziebart, D.A. (1995): “An empirical test of the signaling effect of management's earnings forecasts: a decomposition of the earnings surprise and forecast surprise effects", Journal of Accounting, Auditing \& Finance, 10 (4): 787-802.

Appendix 1. Companies (in percent) disclosing each variable by economic groups

\begin{tabular}{|c|c|c|c|c|c|c|c|c|c|c|}
\hline & EG0 & EG1 & EG2 & EG3 & EG4 & EG5 & EG6 & EG7 & EG8 & EG9 \\
\hline V.1 & $100.00 \%$ & $80.00 \%$ & $100.00 \%$ & $100.00 \%$ & $93.33 \%$ & $85.00 \%$ & $89.47 \%$ & $78.57 \%$ & $80.00 \%$ & $83.33 \%$ \\
\hline V.2 & $23.08 \%$ & $5.71 \%$ & $0.00 \%$ & $16.67 \%$ & $10.00 \%$ & $7.50 \%$ & $7.89 \%$ & $14.29 \%$ & $12.94 \%$ & $0.00 \%$ \\
\hline V.3 & $92.31 \%$ & $68.57 \%$ & $90.48 \%$ & $83.33 \%$ & $90.00 \%$ & $77.50 \%$ & $78.95 \%$ & $57.14 \%$ & $57.65 \%$ & $75.00 \%$ \\
\hline V.4 & $23.08 \%$ & $5.71 \%$ & $0.00 \%$ & $16.67 \%$ & $6.67 \%$ & $7.50 \%$ & $5.26 \%$ & $7.14 \%$ & $3.53 \%$ & $0.00 \%$ \\
\hline V.5 & $92.31 \%$ & $68.57 \%$ & $85.71 \%$ & $91.67 \%$ & $66.67 \%$ & $75.00 \%$ & $76.32 \%$ & $78.57 \%$ & $78.82 \%$ & $75.00 \%$ \\
\hline V.6 & $100.00 \%$ & $62.86 \%$ & $90.48 \%$ & $91.67 \%$ & $73.33 \%$ & $60.00 \%$ & $65.79 \%$ & $71.43 \%$ & $68.24 \%$ & $75.00 \%$ \\
\hline V.7 & $7.69 \%$ & $2.86 \%$ & $9.52 \%$ & $16.67 \%$ & $3.33 \%$ & $0.00 \%$ & $2.63 \%$ & $7.14 \%$ & $9.41 \%$ & $0.00 \%$ \\
\hline V.8 & $84.62 \%$ & $74.29 \%$ & $71.43 \%$ & $83.33 \%$ & $83.33 \%$ & $62.50 \%$ & $52.63 \%$ & $71.43 \%$ & $70.59 \%$ & $41.67 \%$ \\
\hline V.9 & $15.38 \%$ & $2.86 \%$ & $4.76 \%$ & $16.67 \%$ & $0.00 \%$ & $7.50 \%$ & $7.89 \%$ & $0.00 \%$ & $2.35 \%$ & $0.00 \%$ \\
\hline V.10 & $30.77 \%$ & $17.14 \%$ & $28.57 \%$ & $16.67 \%$ & $20.00 \%$ & $30.00 \%$ & $15.79 \%$ & $7.14 \%$ & $12.94 \%$ & $16.67 \%$ \\
\hline V.11 & $53.85 \%$ & $71.43 \%$ & $66.67 \%$ & $58.33 \%$ & $60.00 \%$ & $57.50 \%$ & $57.89 \%$ & $35.71 \%$ & $61.18 \%$ & $58.33 \%$ \\
\hline V.12 & $15.38 \%$ & $14.29 \%$ & $14.29 \%$ & $25.00 \%$ & $20.00 \%$ & $12.50 \%$ & $18.42 \%$ & $28.57 \%$ & $8.24 \%$ & $16.67 \%$ \\
\hline V.13 & $92.31 \%$ & $74.29 \%$ & $85.71 \%$ & $58.33 \%$ & $70.00 \%$ & $62.50 \%$ & $76.32 \%$ & $71.43 \%$ & $71.76 \%$ & $75.00 \%$ \\
\hline V.14 & $92.31 \%$ & $77.14 \%$ & $61.90 \%$ & $50.00 \%$ & $56.67 \%$ & $37.50 \%$ & $47.37 \%$ & $64.29 \%$ & $22.35 \%$ & $16.67 \%$ \\
\hline V.15 & $76.92 \%$ & $62.86 \%$ & $71.43 \%$ & $41.67 \%$ & $56.67 \%$ & $60.00 \%$ & $55.26 \%$ & $78.57 \%$ & $57.65 \%$ & $33.33 \%$ \\
\hline V.16 & $69.23 \%$ & $45.71 \%$ & $66.67 \%$ & $66.67 \%$ & $83.33 \%$ & $52.50 \%$ & $60.53 \%$ & $57.14 \%$ & $54.12 \%$ & $50.00 \%$ \\
\hline V.17 & $84.62 \%$ & $45.71 \%$ & $71.43 \%$ & $33.33 \%$ & $63.33 \%$ & $22.50 \%$ & $36.84 \%$ & $28.57 \%$ & $37.65 \%$ & $50.00 \%$ \\
\hline V.18 & $7.69 \%$ & $5.71 \%$ & $4.76 \%$ & $16.67 \%$ & $13.33 \%$ & $0.00 \%$ & $10.53 \%$ & $7.14 \%$ & $3.53 \%$ & $0.00 \%$ \\
\hline V.19 & $76.92 \%$ & $37.14 \%$ & $76.19 \%$ & $58.33 \%$ & $56.67 \%$ & $50.00 \%$ & $60.53 \%$ & $21.43 \%$ & $48.24 \%$ & $50.00 \%$ \\
\hline V.20 & $100.00 \%$ & $71.43 \%$ & $61.90 \%$ & $91.67 \%$ & $66.67 \%$ & $62.50 \%$ & $63.16 \%$ & $71.43 \%$ & $63.53 \%$ & $41.67 \%$ \\
\hline V.21 & $92.31 \%$ & $62.86 \%$ & $61.90 \%$ & $83.33 \%$ & $83.33 \%$ & $67.50 \%$ & $63.16 \%$ & $50.00 \%$ & $58.82 \%$ & $41.67 \%$ \\
\hline V.22 & $92.31 \%$ & $77.14 \%$ & $95.24 \%$ & $91.67 \%$ & $96.67 \%$ & $82.50 \%$ & $92.11 \%$ & $85.71 \%$ & $70.59 \%$ & $66.67 \%$ \\
\hline V.23 & $76.92 \%$ & $60.00 \%$ & $66.67 \%$ & $66.67 \%$ & $73.33 \%$ & $62.50 \%$ & $47.37 \%$ & $71.43 \%$ & $48.24 \%$ & $41.67 \%$ \\
\hline
\end{tabular}



产 言 焉

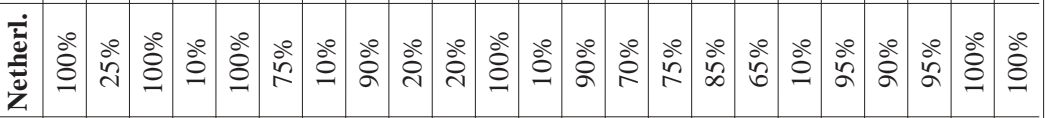

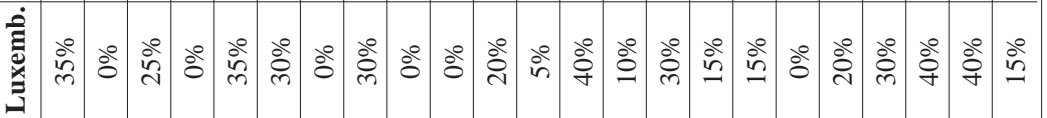
至

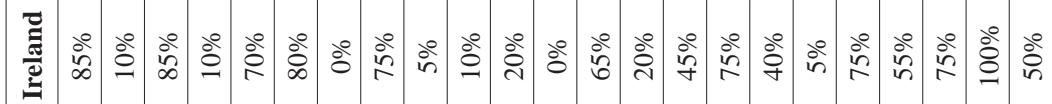

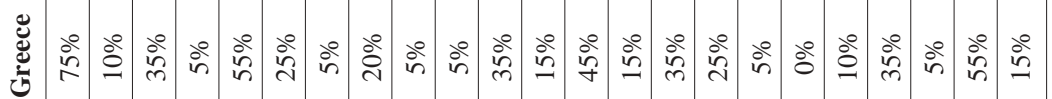

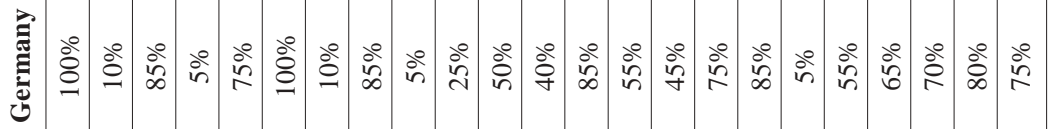
氙

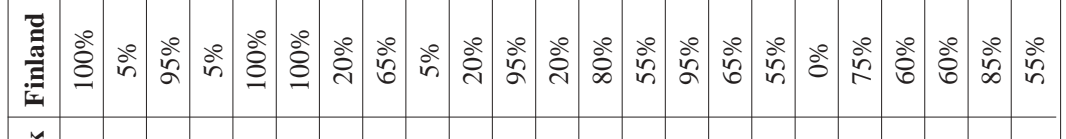

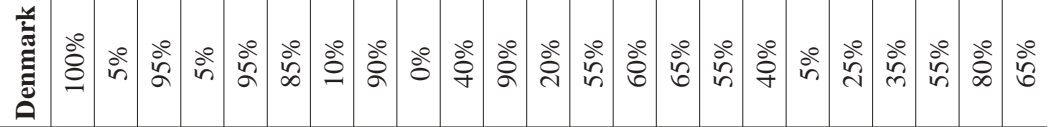
恶 焉

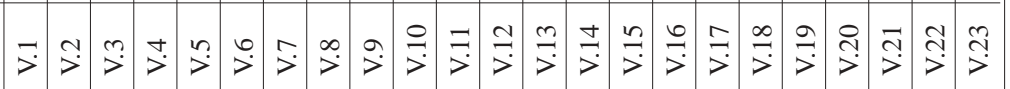

